Cochrane Database of Systematic Reviews

\title{
Methadone maintenance therapy versus no opioid replacement therapy for opioid dependence (Review)
}

Mattick RP, Breen C, Kimber J, Davoli M

Mattick RP, Breen C, Kimber J, Davoli M.

Methadone maintenance therapy versus no opioid replacement therapy for opioid dependence.

Cochrane Database of Systematic Reviews 2009, Issue 3. Art. No.: CD002209.

DOI: 10.1002/14651858.CD002209.pub2.

www.cochranelibrary.com 
TABLE OF CONTENTS

HEADER 1

ABSTRACT

PLAIN LANGUAGE SUMMARY

SUMMARY OF FINDINGS

BACKGROUND

OBJECTIVES

METHODS

RESULTS

Figure 1.

Figure 2.

DISCUSSION

AUTHORS' CONCLUSIONS

ACKNOWLEDGEMENTS

REFERENCES

CHARACTERISTICS OF STUDIES

DATA AND ANALYSES

Analysis 1.1. Comparison 1 Methadone maintenance treatment vs No methadone maintenance treatment, Outcome 1 Retention in treatment.

Analysis 1.2. Comparison 1 Methadone maintenance treatment vs No methadone maintenance treatment, Outcome 2 Morphine positive urine or hair analysis.

Analysis 1.3. Comparison 1 Methadone maintenance treatment vs No methadone maintenance treatment, Outcome 3 Self reported heroin use.

Analysis 1.4. Comparison 1 Methadone maintenance treatment vs No methadone maintenance treatment, Outcome 4 Criminal activity.

Analysis 1.5. Comparison 1 Methadone maintenance treatment vs No methadone maintenance treatment, Outcome 5 Mortality.

APPENDICES

WHAT'S NEW

HISTORY

CONTRIBUTIONS OF AUTHORS

DECLARATIONS OF INTEREST

SOURCES OF SUPPORT

INDEX TERMS 
[Intervention Review]

\section{Methadone maintenance therapy versus no opioid replacement therapy for opioid dependence}

Richard P Mattick ${ }^{1}$, Courtney Breen ${ }^{1}$, Jo Kimber ${ }^{2}$, Marina Davoli ${ }^{3}$

1National Drug and Alcohol Research Centre, University of New South Wales, Sydney, Australia. ${ }^{2}$ Centre for Research on Drugs and Health Behaviour, London School of Hygiene and Tropical Medicine, London, UK. ${ }^{3}$ Department of Epidemiology, ASL RM/E, Rome, Italy

Contact address: Richard P Mattick, National Drug and Alcohol Research Centre, University of New South Wales, National Drug and Alcohol Research Centre, University of New South Wales, Sydney, New South Wales, 2052, Australia. R.Mattick@unsw.edu.au.

Editorial group: Cochrane Drugs and Alcohol Group.

Publication status and date: New search for studies and content updated (no change to conclusions), published in Issue 1, 2010.

Citation: Mattick RP, Breen C, Kimber J, Davoli M. Methadone maintenance therapy versus no opioid replacement therapy for opioid dependence. Cochrane Database of Systematic Reviews 2009, Issue 3. Art. No.: CD002209. DOI: 10.1002/14651858.CD002209.pub2.

Copyright @ 2010 The Cochrane Collaboration. Published by John Wiley \& Sons, Ltd.

\section{A B S T R A C T}

\section{Background}

Methadone maintenance was the first widely used opioid replacement therapy to treat heroin dependence, and it remains the bestresearched treatment for this problem. Despite the widespread use of methadone in maintenance treatment for opioid dependence in many countries, it is a controversial treatment whose effectiveness has been disputed.

\section{Objectives}

To evaluate the effects of methadone maintenance treatment (MMT) compared with treatments that did not involve opioid replacement therapy (i.e., detoxification, offer of drug-free rehabilitation, placebo medication, wait-list controls) for opioid dependence.

\section{Search methods}

We searched the following databases up to Dec 2008: the Cochrane Controlled Trials Register, EMBASE, PubMED, CINAHL, Current Contents, Psychlit, CORK [www. state.vt.su/adap/cork], Alcohol and Drug Council of Australia (ADCA) [www.adca.org.au], Australian Drug Foundation (ADF-VIC) [www.adf.org.au], Centre for Education and Information on Drugs and Alcohol (CEIDA) [www.ceida.net.au], Australian Bibliographic Network (ABN), and Library of Congress databases, available NIDA monographs and the College on Problems of Drug Dependence Inc. proceedings, the reference lists of all identified studies and published reviews; authors of identified RCTs were asked about other published or unpublished relevant RCTs.

\section{Selection criteria}

All randomised controlled clinical trials of methadone maintenance therapy compared with either placebo maintenance or other nonpharmacological therapy for the treatment of opioid dependence.

\section{Data collection and analysis}

Reviewers evaluated the papers separately and independently, rating methodological quality of sequence generation, concealment of allocation and bias. Data were extracted independently for meta-analysis and double-entered.

\section{Main results}

Eleven studies met the criteria for inclusion in this review, all were randomised clinical trials, two were double-blind. There were a total number of 1969 participants. The sequence generation was inadequate in one study, adequate in five studies and unclear in the remaining studies. The allocation of concealment was adequate in three studies and unclear in the remaining studies. Methadone appeared statistically significantly more effective than non-pharmacological approaches in retaining patients in treatment and in the suppression of 
heroin use as measured by self report and urine/hair analysis ( $6 \mathrm{RCTs}, \mathrm{RR}=0.6695 \% \mathrm{Cl} 0.56-0.78$ ), but not statistically different in criminal activity (3 RCTs, RR=0.39; 95\%Cl: 0.12-1.25) or mortality (4 RCTs, RR=0.48; 95\% Cl: 0.10-2.39).

\section{Authors' conclusions}

Methadone is an effective maintenance therapy intervention for the treatment of heroin dependence as it retains patients in treatment and decreases heroin use better than treatments that do not utilise opioid replacement therapy. It does not show a statistically significant superior effect on criminal activity or mortality.

\section{PLAIN LANGUAGE SUMMARY}

\section{Methadone maintenance therapy versus no opioid replacement therapy}

Methadone maintenance treatment can keep people who are dependent on heroin in treatment programs and reduce their use of heroin. Methadone is the most widely used replacement for heroin in medically-supported maintenance or detoxification programs. Several nondrug detoxification and rehabilitation methods are also used to try and help people withdraw from heroin. However the review found that people have withdrawn from trials when they are assigned to a drug-free program. Consequently, there are no trials comparing methadone maintenance treatment with drug-free methods other than methadone placebo trials, or comparing methadone maintenance with methadone for detoxification only. These trials show that methadone can reduce the use of heroin in dependent people, and keep them in treatment programs. 


\section{SUMMARY OF FINDINGS}

\section{Summary of findings for the main comparison.}

Methadone maintenance treatment compared to No methadone maintenance treatment for opioid dependence

Patient or population: patients with opioid dependence

Settings: Prisons, hospitals, community based treatments and research facilities

Intervention: Methadone maintenance treatment

Comparison: No methadone maintenance treatment

\begin{tabular}{|c|c|c|c|c|c|c|}
\hline \multirow[t]{2}{*}{ Outcomes } & \multicolumn{2}{|c|}{ Illustrative comparative risks* $(95 \% \mathrm{CI})$} & \multirow{2}{*}{$\begin{array}{l}\text { Relative effect } \\
(95 \% \mathrm{Cl})\end{array}$} & \multirow{2}{*}{$\begin{array}{l}\text { No of Partici- } \\
\text { pants } \\
\text { (studies) }\end{array}$} & \multirow{2}{*}{$\begin{array}{l}\text { Quality of the } \\
\text { evidence } \\
\text { (GRADE) }\end{array}$} & \multirow[t]{2}{*}{ Comments } \\
\hline & Assumed risk & Corresponding risk & & & & \\
\hline & $\begin{array}{l}\text { No methadone maintenance } \\
\text { treatment }\end{array}$ & $\begin{array}{l}\text { Methadone mainte- } \\
\text { nance treatment }\end{array}$ & & & & \\
\hline $\begin{array}{l}\text { Retention in treatment - Old } \\
\text { studies (pre 2000) } \\
\text { objective }\end{array}$ & \multicolumn{2}{|l|}{ Medium risk population } & $\begin{array}{l}\text { RR } 3.05 \\
\text { (1.75 to } 5.35)\end{array}$ & $\begin{array}{l}505 \\
(3)\end{array}$ & $\begin{array}{l}\oplus \oplus \oplus \oplus \\
\text { high } 1,2\end{array}$ & \\
\hline \multirow{2}{*}{$\begin{array}{l}\text { Retention in treatment - New } \\
\text { studies }\end{array}$} & \multicolumn{2}{|l|}{ Medium risk population } & \multirow{2}{*}{$\begin{array}{l}\text { RR } 4.44 \\
\text { (3.26 to } 6.04)\end{array}$} & \multirow{2}{*}{$\begin{array}{l}750 \\
(4)\end{array}$} & \multirow{2}{*}{$\begin{array}{l}\oplus \oplus \oplus \oplus \\
\text { high 2,3 }\end{array}$} & \\
\hline & 154 per 1000 & $\begin{array}{l}\mathbf{6 8 4} \text { per } 1000 \\
(502 \text { to } 930)\end{array}$ & & & & \\
\hline $\begin{array}{l}\text { Morphine positive urine or hair } \\
\text { analysis } \\
\text { objective }\end{array}$ & \multicolumn{2}{|l|}{ Medium risk population } & $\begin{array}{l}\text { RR } \mathbf{0 . 6 6} \\
(0.56 \text { to } 0.78)\end{array}$ & $\begin{array}{l}1129 \\
(6)\end{array}$ & $\begin{array}{l}\oplus \oplus \oplus \oplus \\
\text { high }\end{array}$ & \\
\hline \multirow{2}{*}{$\begin{array}{l}\text { Criminal activity } \\
\text { objective }\end{array}$} & \multicolumn{2}{|l|}{ Medium risk population } & \multirow{2}{*}{$\begin{array}{l}\text { RR } \mathbf{0 . 3 9} \\
(0.12 \text { to } 1.25)\end{array}$} & \multirow{2}{*}{$\begin{array}{l}363 \\
(3)\end{array}$} & \multirow{2}{*}{$\begin{array}{l}\oplus \oplus \oplus \ominus \\
\text { moderate } 4\end{array}$} & \\
\hline & 118 per 1000 & $\begin{array}{l}\mathbf{4 6} \text { per } 1000 \\
(14 \text { to } 148)\end{array}$ & & & & \\
\hline $\begin{array}{l}\text { Mortality } \\
\text { objective }\end{array}$ & \multicolumn{2}{|l|}{ Medium risk population } & $\begin{array}{l}\mathbf{R R} \mathbf{0 . 4 8} \\
(0.1 \text { to } 2.39)\end{array}$ & $\begin{array}{l}576 \\
(4)\end{array}$ & $\begin{array}{l}\oplus \oplus \oplus \ominus \\
\text { moderate } 4\end{array}$ & \\
\hline
\end{tabular}


*The basis for the assumed risk (e.g. the median control group risk across studies) is provided in footnotes. The corresponding risk (and its $95 \%$ confidence interval) is based on the assumed risk in the comparison group and the relative effect of the intervention (and its $95 \% \mathrm{Cl}$ ).

$\mathrm{Cl}$ : Confidence interval; RR: Risk ratio

GRADE Working Group grades of evidance

High quality: Further research is very unlikely to change our confidence in the estimate of effect.

Moderate quality: Further research is likely to have an important impact on our confidence in the estimate of effect and may change the estimate.

Low quality: Further research is very likely to have an important impact on our confidence in the estimate of effect and is likely to change the estimate.

Very low quality: We are very uncertain about the estimate.

1 RR 3.05

2 Other Cochrane review showing dose related effect : Faggiano F, Vigna-Taglianti F, Versino E, Lemma P. Methadone maintenance at different dosages for opioid dependence.

Cochrane Database of Systematic Reviews 2003, Issue 3. Art. No.: CD002208. DOI: 10.1002/14651858.CD002208

RR 4.4

4 Too few numbers of events observed 


\section{B A C K G R O U N D}

\section{Description of the intervention}

Currently, the major form of medical therapy for heroin dependence internationally involves orally administered methadone. Methadone is an analgesic medication developed to treat pain in the 1940s. It has been, and is still, prescribed widely for the management of pain in America, Australia and Europe.

It was in New York in the 1960s, during an increase in heroin use and heroin dependence, that researchers (Dole 1965; Dole Nyswander 1967) examined different prescribed opioids to manage heroin dependence, and reported that they found that methadone was most suitable to the task. They believed that long-term heroin use caused a permanent metabolic deficiency in the central nervous system and an associated physiological disease, which required regular administration of opiates to correct the metabolic deficiency (Dole Nyswander 1967). The disorder of opioid dependence has been represented in the International Classification of Disease of the World Health Organisation. It is a chronic or long-term and relapsing disorder, and some believe that it requires ongoing maintenance medication.

\section{How the intervention might work}

The aspects of methadone that have led to its use as a substitute drug for heroin include the number of pharmacological features of opioids. At the basis of methadone maintenance treatment (MMT) is the observation that opioid analgesics can be substituted for one another (Jaffe 1990). Methadone at adequate doses (of $20 \mathrm{mg}$ to more than $100 \mathrm{mg}$ ) prevents or reverses withdrawal symptoms (Ward 1992), and thus reduces the need to use illegal heroin (Jaffe 1990). Methadone remains effective for approximately 24 hours, requiring a single daily dose rather than the more frequent administration of three to four times daily which occurs with the shorter-acting heroin (Jaffe 1990). Methadone can "block" the euphoric effects of heroin, discouraging illicit use and thereby relieving the user of the need or desire to seek heroin (Dole 1969). This allows the opportunity to engage in normative activities, and "rehabilitation" if necessary. Methadone can cause death in overdosage, like other similar medications such as morphine, and for this reason it is a treatment which is dispensed under medical supervision and relatively strict rules. In summary, methadone is a long-acting opioid analgesic with well-understood pharmacological characteristics which make it suitable for stabilising opioid dependent patients in a maintenance treatment approach.

There is evidence that the quality of the therapeutic relationship with staff in methadone clinics plus the intensity of these ancillary services, combined with the dose of methadone prescribed will all act to enhance the outcome for methadone treatment (Ward 1992), although this is not the focus of this review.

\section{Why it is important to do this review}

Methadone maintenance treatment remains one of the best researched treatments for opioid dependence (Cooper 1983; Gerstein 1990; Hargreaves 1983; Mattick 1993; Ward 1992). It is the only treatment for opioid dependence which has been clearly demonstrated to reduce illicit opiate use more than either no-treatment (Dole 1969; Yancovitz 1991; Dolan 2003; Schwartz 2006, Kinlock 2007), drug-free treatment (Gunne 1981), placebo medication (Newman 1979; Strain 1993a), or detoxification (Vanichseni 1991; Gruber 2008; Sees 2000) in clinical controlled trials. These trials have been conducted by different research groups, in markedly differing cultural settings, yet have converged to provide similar results.

\section{O B J E C T IVES}

The present systematic review aimed to provide an evaluation of the effectiveness of methadone maintenance treatment on opioid dependence compared with treatments that did not include an opioid replacement therapy. The focus of the review is on retention in treatment, opioid use as measured by objective urine results and from self-report, as well as criminal activity and patient mortality.

\section{METHODS}

\section{Criteria for considering studies for this review \\ Types of studies}

The literature was reviewed for all clinical controlled trials of MMT against another treatment which does not use opioid replacement therapy.

\section{Types of participants}

Individuals who were opioid dependent were the target population for this review. No distinction was made between those using heroin and those who have been in methadone treatment prior to entering the research trial treatment. No restrictions were imposed in terms of studies of outpatients, inpatients, those with comorbid states, etc.

\section{Types of interventions}

Interventions were included if they used methadone maintenance therapy (MMT). The MMT interventions were included even where they also employed other treatments, such as behavioural therapies or outpatient rehabilitation. The control groups were treated with placebo medication, withdrawal or detoxification (with or without ancillary medication), drug-free rehabilitation treatment (such as therapeutic communities), and no treatment or wait-list controls.

\section{Types of outcome measures}

\section{Primary outcomes}

1. retention in treatment

2. mortality

3. proportion of urine or hair analysis results positive for heroin (or morphine)

4. self-reported heroin use

5. criminal activity

\section{Secondary outcomes}

1. use of other drugs

2. physical health

3. psychological health 


\section{Search methods for identification of studies}

\section{Electronic searches}

1.Cochrane Central Register of Controlled Trials, which includes the Cochrane Drugs and Alcohol Group Register of Trials (CENTRAL The Cochrane Library issue 4, 2008)

2.PubMed (January 2001 - December 2008)

3.Embase (January 2001- December 2008)

4.CINAHL (January 2001 - December 2008)

For details on searches see Appendix 1; Appendix 2; Appendix 3; Appendix 4

The search strategy was developed in consultation with a drug and alcohol research information specialist.

\section{Searching other resources}

1. Some of the main electronic sources of ongoing trials (National Research Register, meta-Register of Controlled Trials; Clinical Trials.gov, Agenzia Italiana del Farmaco)

2. Conference proceedings likely to contain trials relevant to the review (College on Problems of Drug Dependence - CPDD)

3. Library of Congress databases were also searched for studies and book chapters with the key terms: methadone, clinical trial, and randomised control trial.

4. National focal points for drug research (e.g., National Institute of Drug Abuse (NIDA), National Drug \& Alcohol Research Centre (NDARC))

5. Reference lists of all relevant papers to identify further studies.

6. Authors of identified RCT's were consulted to find out if there were any other published or unpublished RCT's comparing the efficacy of methadone maintenance vs against another treatment which does not use opioid replacement therapy.

7. As several drug and alcohol journals are not indexed on the main electronic databases, the following databases were searched up until December 2008:

- "Current Contents

- "Psychlit

- "CORK [www. state.vt.su/adap/cork]

- "Alcohol and Drug Council of Australia (ADCA) [www.adca.org.au]

- "Australian Drug Foundation (ADF -VIC) [www.adf.org.au]

- "Centre for Education and Information on Drugs and Alcohol (CEIDA) [www.ceida.net.au]

- "Australian Bibliographic Network (ABN).

All searches included non-English language literature and studies with English abstracts were assessed for inclusion. When considered likely to meet inclusion criteria, studies were translated.

\section{Data collection and analysis}

\section{Selection of studies}

Each potentially relevant study located in the search was obtained and independently assessed for inclusion by two of three reviewers. Data extraction for each study was undertaken by the same two reviewers, again independently.

\section{Data extraction and management}

Each potentially relevant study located in the search was obtained and independently assessed for inclusion by two of three reviewers. Data extraction for each study was undertaken by the same two reviewers, again independently. A standardised checklist was used for data extraction. Disagreement was dealt with by the third reviewer, acting as a mediator. If unresolved disagreements on inclusion, study quality or extraction occurred they were referred to the editor.

\section{Assessment of risk of bias in included studies}

Due the type of comparisons analysed (MMT versus methadone detoxification or waiting list), blinding is often difficult to apply. As such, methodological quality was assessed by assessment of the randomisation procedure and the likelihood that randomisation was not biased:

A. Low risk of bias (allocation clearly independent of clinical staff); B. Moderate risk of bias (some doubt about the independence of the allocation procedure); and

C. High risk of bias (inadequate separation of randomisation from clinical staff).

\section{Measures of treatment effect}

A standardised effect size was calculated for each study, based on the main outcome measure reported. Where possible (relative risks and 95\% confidence intervals for dichotomous outcomes (retention) using a random effects model and standardised mean differences for continuous outcomes were presented. To assess for statistical heterogeneity a test of homogeneity was undertaken. A pooled effect size estimate was derived for each domain of measurement (retention in treatment, urine analysis results for heroin/morphine ), self-reported heroin use, and criminal activity. The retention in treatment and urine results were reported as the number of patients retained or the number with a morphinepositive urine result at follow-up, a form of reporting that allowed for dichotomous analysis of those data.

\section{Data synthesis}

The results were integrated from the meta-analytic review into a discussion taking into consideration other publications including large-scale observational studies, studies of the pharmacology of methadone, and studies of the effect of MMT on HIV seroconversion. Convergence of the evidence from the meta-analysis and the narrative review was taken to indicate a robust conclusion.

\section{RE S U L T S}

\section{Description of studies}

We considered fourteen studies for inclusion, three were excluded because they did not satisfy the inclusion criteria (see Characteristics of excluded studies table) and eleven were included (Characteristics of included studies Charachteristics table) with a total of 1969 participants.

\section{Included studies}

Eleven studies were included in this review. Refer to Characteristics of included studies Table for more detailed information. 


\section{Treatment regimes and settings}

The first study by Dole (Dole 1969) was a two group randomised trial where patients either received methadone or placed on a wait- list. The study by Gunne (Gunne 1981) randomly allocated patients to receive methadone maintenance or to be allocated to a drug-free rehabilitation. None of the patients allocated to drug-free rehabilitation took up the offer, refusing treatment after they had learnt that they would not receive methadone. There were two placebo controlled trials (Newman 1979, Strain 1993a). Finally, there have been six randomised clinical trials, three assessing methadone maintenance against methadone detoxification (Vanichseni 1991, Sees 2000, Gruber 2008) and the others assessing methadone maintenance against a wait-list control (Yancovitz 1991, Dolan 2003, Schwartz 2006).

Three studies were conducted in a prison setting (Dole 1969, Dolan 2003 , Kinlock 2007). The remainder were conducted in medical or research facilities.

The sample sizes in these studies were sometimes small, in that two studies having sample sizes of 32 and 34 (Dole 1969, Gunne 1981), respectively. The remaining seven studies had sample sizes ranging from 100 to 240 (Newman 1979, Vanichseni 1991, Sees 2000, Gruber 2008) patients up to 247 to 382 patients (Strain 1993a, Yancovitz 1991, Dolan 2003, Schwartz 2006).

The dosages of methadone used in these studies appears to have been adequate. In the first study, (Dole 1969) the dose at release from prison was 35 milligrams but patients were entered into a community program where blockade doses of approximately 100 milligrams were standard. In the study by Gunne (Gunne 1981) the doses are not clearly stated. The placebo-controlled study by Newman (Newman 1979) have an average dose on 97 milligrams per day. An average of 74 milligrams per day was reported in the study from Thailand (Vanichseni 1991). Strain (Strain 1993a) used doses of methadone of 50 and 20 milligrams per day. The study by Dolan (Dolan 2003) had a mean methadone dose of $61 \mathrm{mg}$. The study by Schwartz (Schwartz 2006) had a mean dose of $78.4 \mathrm{mg}$ and Sees (Sees 2000) had a mean methadone dose of $86.3 \mathrm{mg}$. The study by Gruber (Gruber 2008) used a methadone dose range of $60-90 \mathrm{mg}$ and Kinlock (Kinlock 2007) set a target dose of 60mg. Finally, the study by Yancovitz (Yancovitz 1991) used a maintenance dose of approximately 80 milligrams per day. As such, the results from the studies appear to use moderate to high doses on average.

\section{Duration of the trials}

As shown in the table of included studies, the interventions generally lasted for significant time of several weeks up to two years, although one study only ran 45 days (Vanichseni 1991).

\section{Countries in which the studies were conducted}

The studies were conducted in a range of countries including; USA (Dole 1969, Yancovitz 1991, Strain 1993a, Sees 2000, Schwartz 2006, Gruber 2008), Sweden Gunne 1981), Australia (Dolan 2003), Hong Kong (Newman 1979) and Thailand (Vanichseni 1991).

\section{Participants}

The participants ( $\mathrm{N}=1969)$ were largely typical of heroin dependant individuals, in terms of age and gender characteristics. In some studies, only males were included but where females were included the gender distribution was as one would expect, with majority of the participants being male. They tended to be approximately 30 to 40 years of age, often unemployed and unmarried, with previous treatment histories and prevalence of use of other drugs, consistent with what is known about heroin users presenting for treatment.

\section{Types of comparisons}

The review compared methadone maintenance treatment with no methadone maintenance treatment. All studies were assessed to determine whether they provided data on retention in treatment, codeable results from urine/hair analysis, self-reported drug use (particularly heroin use), criminal activity and mortality. After reviewing the studies, it was realised that it was not possible to include urine/hair results for cocaine and benzodiazepines as these were not reported in an analysable form for most studies. It was not possible to analyse data on either cocaine or benzodiazepine positive urines from these studies. However, it was possible to code data on retention in treatment, morphine positive urine or hair analysis, self-reported heroin use, criminal activity and mortality.

\section{Excluded studies}

Three studies were not included. Refer to the Characteristics of excluded studies for the reason for exclusion.

\section{Risk of bias in included studies}

\section{Allocation}

The study conducted by Dole (Dole 1969) had inadequate sequence generation for randomisation and was unclear on the concealment of allocation. The studies conducted by Sees 2000, Dolan 2003, Schwartz 2006, Gruber 2008 and Kinlock 2007 had adequate sequence generation for randomisation. The study by Dolan 2003 also had adequate concealment of allocation, as did the studies by Yancovitz 1991 and Newman 1979. It was unclear if the remaining studies had adequate sequence generation and concealment of allocation.

\section{Blinding}

Of the eleven studies included in this review, two were placebocontrolled trials (Newman 1979, Strain 1993a). Both of these studies were double-blind but Strain 1993a did not provide sufficient data to be confident about the concealment of allocation. The remaining studies were not blinded.

\section{Incomplete outcome data}

All studies addressed the issue of incomplete outcome data adequately and were independently deemed by reviewers to be free of other major bias (Figure 1; Figure 2). 
Figure 1. Methodological quality graph: review authors' judgements about each methodological quality item presented as percentages across all included studies.

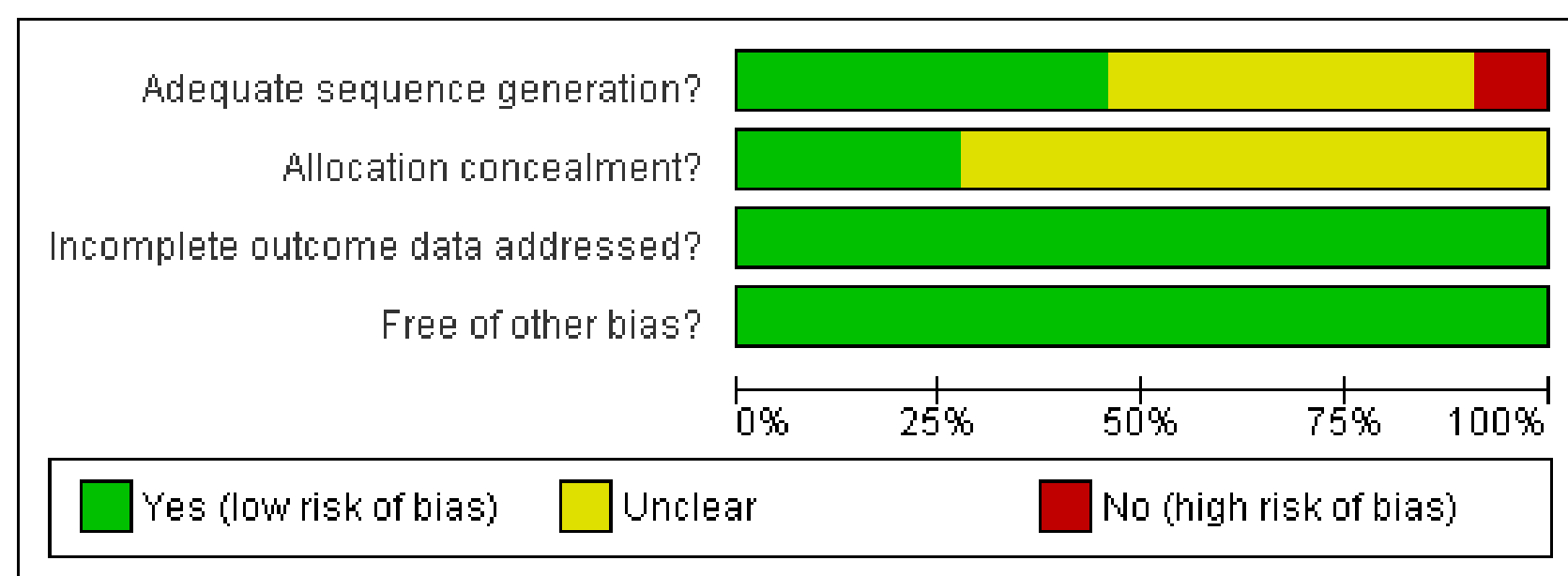


Figure 2. Methodological quality summary: review authors' judgements about each methodological quality item for each included study.

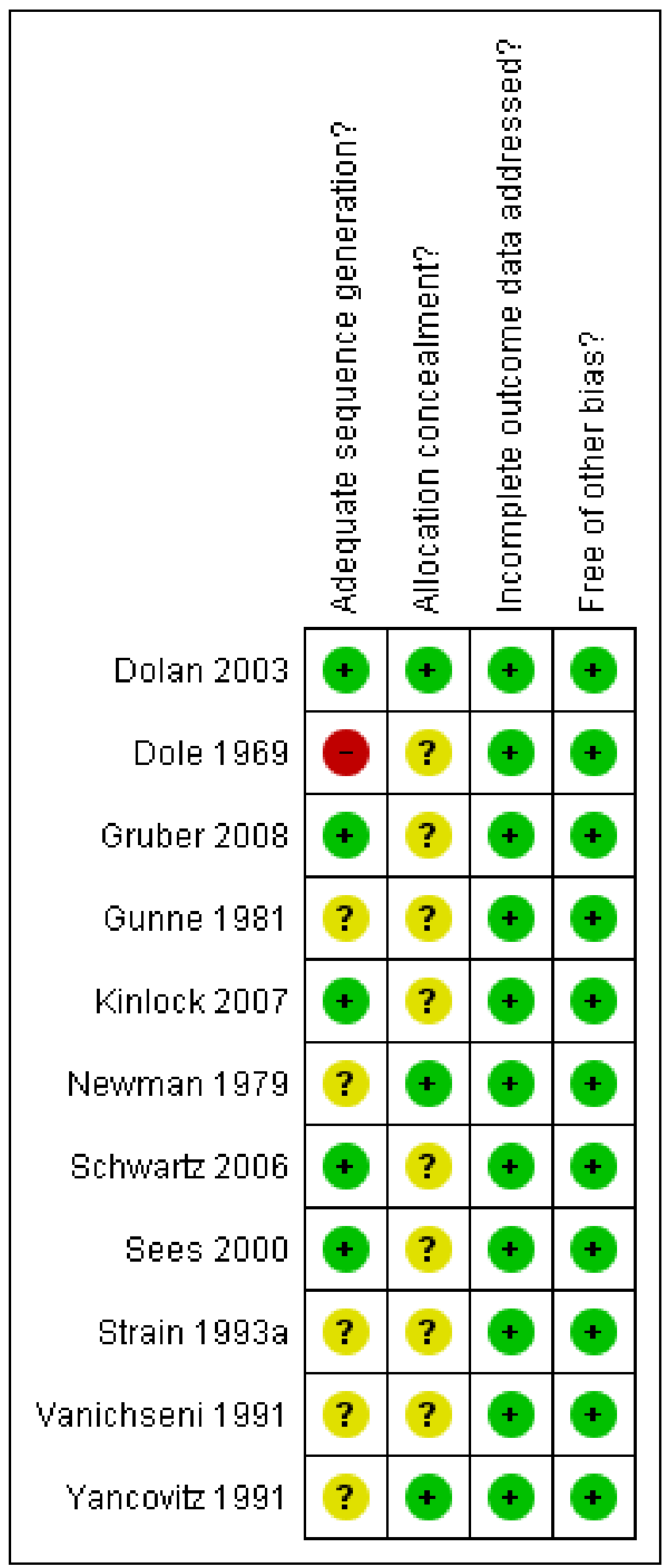

\section{Effects of interventions}

See: Summary of findings for the main comparison

Methadone maintenance therapy versus no opioid replacement therapy for opioid dependence (Review) 


\section{Results of meta-analyses}

\section{Comparison 01 Methadone maintenance treatment versus no methadone maintenance treatment}

\subsection{Retention in treatment:}

7 studies; 1287 participants (Gruber 2008, Kinlock 2007, Newman 1979, Schwartz 2006, Sees 2000, Strain 1993a, Vanichseni 1991). The relative risk on a random effect model was applied. The chi-square test for heterogeneity was significant $(p<0001)$ so a pooled estimate is not reported. However, the results from all studies showed that methadone has a superior retention rate compared with control conditions.Subgroup analysis was conducted examining the older studies (pre 2000) and the more recent studies, as differences in results can occur over time. The heterogeneity for the older studies (Newman 1979, Strain 1993a, Vanichseni 1991; 3 studies, 505 patients) was significant, as indicated in the previous published review. (Analysis 1.1.1). Data from the newer studies (Gruber 2008, Kinlock 2007, Schwartz 2006, Sees 2000) show the superiority of methadone over control in retaining patients in treatment (4 studies, 750 patients, $\mathrm{RR}=4.44,95 \% \mathrm{Cl}: 3.26-2.04)$. The test for heterogeneity was not significant (Analysis 1.1.2).

\subsection{Morphine positive urine or hair analysis}

6 studies, 1129 participants (Dolan 2003, Gruber 2008, Kinlock 2007, Schwartz 2006, Vanichseni 1991, Yancovitz 1991). Turning to the data from morphine positive urine/ hair analysis, five studies (Vanichseni 1991, Yancovitz 1991, Dolan 2003, Schwartz 2006, Gruber 2008) provided dichotomous data as to whether patients had morphine positive urine/hair at follow up. The results from these studies providing data on the presence/absence of morphine in urine at the follow-up showed an advantage of methadone above the control conditions ( 6 studies, 1129 patients $\mathrm{RR}=0.66$, $95 \% \mathrm{Cl}$ 0.56-0.78), in this case detoxification, wait-list or control, in reducing heroin use as shown by a lack of heroin metabolites in urine or hair. (Analysis 1.2)

\subsection{Self-reported heroin use}

6 studies, 682 participants (Dolan 2003, Dole 1969, Gruber 2008, Gunne 1981, Kinlock 2007, Vanichseni 1991). The results from the objective data on morphine positive urine/hair analysis were also supported by self-report data from five studies. In particular, studies from the USA, Sweden and Australia (Dole 1969, Gunne 1981, Yancovitz 1991, Dolan 2003, Kinlock 2007) all concurred to show an advantage for methadone above control in reduction of heroin use as reported by the patients. The study by Gruber 2008 showed no difference between groups. The test for heterogeneity was significant $(p<0.000001)$ so a pooled estimate is not reported. (Analysis 1.3)

\subsection{Criminal activity}

3 studies, 363 participants (Dole 1969, Gunne 1981, Yancovitz 1991). The results for the criminal activity variable, available for three studies, were consistent with the reduction in heroin use, even though the advantage for methadone beyond control in reducing criminal activity was not statistically significant (3 studies, 363 patients $\mathrm{RR}=0.39,95 \% \mathrm{Cl}: 0.12-1.25)$. The test for heterogeneity was not significant. (Analysis 1.4)

\subsection{Mortality}

4 studies, 576 participants (Gunne 1981, Kinlock 2007, Newman 1979, Yancovitz 1991). Turning finally to the evidence concerning the ability of methadone to prevent deaths, available for four studies, the results showed a trend in favour of methadone that was not statistically significant (4 studies, 576 patients $\mathrm{RR}=0.48,95 \% \mathrm{Cl}$ : 0.10-2.39). (Analysis 1.5)

Other measures (e.g., use of other drugs, physical health, and psychological health) are too infrequently and irregularly reported in the literature to be usefully integrated in the quantitative review.

The results are also summarized in the Summary of findings table 1

\section{DISCUSSION}

\section{Summary of main results}

The results of the meta-analysis indicate that methadone is able to retain patients in treatment better than the drug-free alternatives (placebo medication, offer of drug-free treatment, detoxification, or wait-list control), to suppress heroin use based on morphine (the heroin metabolite) found in urine/hair samples, and patient self-report. There was a greater reduction in criminal activity and mortality among the MMT patients, but these differences were not statistically significant. There is evidence from other literature showing mortality (Gibson 2008, Clausen 2008) and criminal activity (Lind 2005) is decreased in patients who are in methadone treatment.

\section{Overall completeness and applicability of evidence}

Interestingly, the results from these eleven randomised trials all showed statistically significant positive benefits from methadone treatment, despite their small sample sizes. Additional support for the efficacy of methadone maintenance treatment comes from the results of many observational studies wherein some statistical form of control has addressed alternative explanations of apparent effectiveness. These large scale observational studies have generally supported the results from the randomised clinical trials in showing that methadone maintenance treatment reduces the use of heroin and decreases criminal activity (Ward 1998). As noted earlier there is a broader international literature showing advantages for methadone beyond other treatments in terms of reduction of death (Ward 1998), even though the randomised trial data do not show this result.

Another relevant outcome to be considered would be seroconversion for HIV, which is the object of a separate Cochrane review (Gowing 2004). Methadone maintenance treatment has been shown to reduce HIV risk taking behaviour (specifically reduction in needle sharing) and thereby has achieved a reduction in the transmission of HIV. Consistent with this it has been shown that methadone maintenance treatment is protective of patients, reducing HIV infection in geographic locations where HIV had spread rapidly among injecting drug users who had not entered treatment. We have commented elsewhere on two large prospective cohort studies in the USA which found methadone maintenance treatment protected against HIV infection (Ward 1998). This outcome could not be addressed here as there are no randomised trials of methadone that have included HIV status as a measure, the evidence coming from observational studies. 


\section{Quality of the evidence}

It is notable that the doses of methadone used in the randomised clinical trials are probably slightly higher than are being used currently in routine clinical practice in some parts of the world. This relative underdosing in clinical practice may lead to a reduction in the effectiveness of methadone, as the response to methadone treatment is dose-dependent. In addition, it is important to recognise that methadone treatment in these trials was often provided with substantial ancillary services. These ancillary services have included counselling, psycho-social services, medical services and often psychiatric care. The quality of the therapeutic relationship with staff in methadone clinics plus the intensity of these ancillary services, combined with the dose of methadone prescribed will all act to enhance the outcome for methadone treatment. The extent that clinical programs move away from such an approach might be expected to impact on the effectiveness of methadone.

This does not imply that methadone maintenance treatment will become ineffective. Even allowing for some reduction in effectiveness when methadone is not provided in the fashion that it has been in the clinical trials, it is still likely to be effective. The effects of methadone may be modest, if they are judged by unrealistic expectations of patients can easily achieve enduring abstinence from opioid drugs. Methadone nonetheless attracts and retains more patients than alternative treatments, and it does produce better outcomes amongst those who complete treatment. Methadone maintenance appears to provide better outcomes than simple detoxification programs, where the evidence suggests that short-term detoxification has no enduring effect on drug use (Mattick 1996).

\section{AUTHORS' CONCLUSIONS}

\section{Implications for practice}

The implications of the results of the meta-analytic review conducted and reported herein for clinical practice are that methadone maintenance treatment is an effective intervention for the management of heroin dependence. Methadone retains patients in treatment and reduces heroin use. Methadone should be supported as a maintenance treatment for heroin dependence.

\section{Implications for research}

Overall there are a relatively limited number of randomised clinical trials on the efficacy of methadone treatment compared to placebo. It does not seem feasible at this stage to conduct further randomised trials of methadone treatment. However, evidence on reduction of criminal activity and mortality from clinical trials is lacking calling for an additional systematic review of observational studies. Moreover, monitoring of the outcome of standard methadone treatment in clinical practice may be important as a research activity to demonstrate its ongoing effectiveness, or to determine whether its effectiveness is being compromised through the reduction of ancillary services or reduction in adequate dose levels.

A number of measures (e.g., of other drug use, physical health, and psychological health) were too infrequently and irregularly reported in the literature to be usefully integrated in the quantitative review, but future research might address these important areas.

\section{ACKNOWLEDGEMENTS}

We acknowledge the assistance of the Cochrane Review Group Coordinating Centre, Rome.

Laura Amato from the Rome Editorial Base provided copyediting on the drafts of this review.

Marica Ferri from the Rome Editorial Base provided comments and copyediting on the drafts of the previous version of the review as well as Roberto D'Amico from the Cochrane Statistical Methods Group provided advice on statistical analysis issues. 


\section{R E F E R E N C E S}

\section{References to studies included in this review}

Dolan 2003 \{published data only\}

Dolan KA, Shearer J, MacDonald M, Mattick RP, Hall W, Wodak A. A randomised controlled trial of methadone maintenance treatment versus wait list control in an Australian prison system. Drug and Alcohol Dependence 2003;72:59-65.

Dole 1969 \{published data only\}

Dole V, Robinson J, Orraca J, Towns E, Searcy P, Caine E. Methadone treatment of randomly selected criminal addicts. New England Journal of Medicine 1969;280:1372-5.

\section{Gruber 2008 \{published and unpublished data\}}

Gruber VA, Delucchi KL, Kielstein A, Batki SL. A randomised trial of 6-month methadone maintenance with standard or minimal counselling versus 21 -day methadone detoxification.. Drug and Alcohol Dependence 2008;94:199-206.

\section{Gunne 1981 \{published data only\}}

Gunne L, Gronbladh L. The Swedish methadone maintenance program: A controlled study. Drug and Alcohol Dependence $1981 ; 7: 249-56$

\section{Kinlock 2007 \{published data only\}}

Kinlock TW, Gordon MS, Schwartz RP, O'Grady K, Fitzgerald TT, Wilson M. A randomised clinical trial of methadone maintenance for prisoners: Results at 1 month post release. Drug and Alcohol Dependence 2007;91:220-7.

\section{Newman 1979 \{published data only\}}

Newman R, Whitehill W. Double-blind comparison of methadone and placebo maintenance treatments of narcotic addicts in Hong Kong. Lancet 1979;September 8:485-8.

\section{Schwartz 2006 \{published data only\}}

Schwartz RP, Highfield DA, Jaffe JH, Brady JV, Butler CB, Rouse $\mathrm{CO}$, et al. A randomised controlled trial of interim methadone maintenance. Archives of General Psychiatry 2006;63:102-9.

\section{Sees 2000 \{published data only\}}

Sees KL, Delucchi KL, Masson C, Rosen A, Clark HW, Robillard H, et al. Methadone maintenance vs 180-day psychosocially enriched detoxification for treatment of opioid dependence. A randomised controlled trial. Journal of the American Medical Association 2000;283(10):1303-10.

\section{Strain 1993a \{published data only\}}

Strain E, Stitzer M, Leibson I, Bigelow G. Dose-response effects of methadone in the treatment of opioid dependence. Ann Intern Med 1993;119:23-7.

\section{Vanichseni 1991 \{published data only\}}

Vanichseni S, Wongsuwan B, Choopanya K, Wongpanich K. A controlled trial of methadone in a population of intravenous drug users in Bangkok: implications for prevention of HIV. International Journal of the Addictions 1991;26(12):1313-20.
Yancovitz 1991 \{published data only\}

Yancovitz S, Des Jarlais D, Peskoe Peyser N, Drew E, Friedman P, Trigg $\mathrm{H}$, et al. A randomised trial of an interim methadone maintenance clinic. Am J of Pub Health 1991;81:1185-91.

\section{References to studies excluded from this review}

Bale 1980 \{published data only\}

Bale R, Van Stone W, Kuldau J, Engelsing T, Elashoff R, Zarcone V. Therapeutic communities vs methadone maintenance. A prospective controlled study of narcotic addiction treatment: design and one year follow-up. Arch Gen Psych 1980;37:179-93.

Dolan 2005 \{published data only\}

Dolan KA, Shearer J, White B, Zhou J, Kaldor J, Wodak A. Fouryear follow up of imprisoned male heroin users and methadone treatment: mortality, re-incarceration and hepatitis $\mathrm{C}$ infection. Addiction 2005;100:820-8.

Schwartz 2007 \{published data only\}

Schwartz RP, Jaffe JH, Highfield DA, Callaman JM, O'Grady KE. $A$ randomized controlled trial of interim methadone maintenance: 10-month follow-up. Drug and Alcohol Dependence 2007;86:30-6.

\section{Additional references}

Clausen 2008

Clausen T, Anchersen K, Waal H. Mortality prior to, during and after opioid maintenance treatment (OMT): A national prospective cross-registry study. Drug and Alcohol Dependence 2008;94:151-7.

\section{Cooper 1983}

Cooper J, Altman F, Brown, B, Czechowicz D. Research on the treatment of narcotic addiction: State of the art. Rockville, MD: National Institute on Drug Abuse, 1983.

\section{Dole 1965}

Dole V, Nyswander M. A medical treatment of diacetylmorphine (heroin) addiction. JAMA 1965;193:80-4

\section{Dole Nyswander 1967}

Dole V, Nyswander M. Heroin addiction - a metabolic disease. Arch Internal Medicine 1967;120:19-24

\section{Gerstein 1990}

Gerstein D, Harwood H. Treating drug problems Volume 1: A study of effectiveness and financing of public and private drug treatment systems. Washington, DC: National Academy Press, 1990.

\section{Gibson 2008}

Gibson A, Degenhardt L, Mattick RP, Ali R, White J, O'Brien S. Exposure to opioid maintenance treatment reduces long-term mortality. Addiction 2008;103:462-8. 


\section{Gowing 2004}

Gowing L, Farrell M, Bornemann R, Ali R. Substitution treatment of injecting opioid users for prevention of HIV infection. Cochrane Database of Systematic Reviews 2004, Issue 4. [DOI: 10.1002/14651858.CD004145]

\section{Hargreaves 1983}

Hargreaves W. Methadone dosage and duration for maintenance treatment.. In: J Cooper, F Altman, B Brown, D Czechowicz editor(s). Research on the treatment of narcotic addiction: State of the art. Rockville, MD: National Institute on Drug Abuse, 1983.

\section{Higgins 2006}

Higgins JPT, Green S. Cochrane Handbook for Systematic Reviews of Interventions 4.2.5. The Cochrane Library 2006;(3).

\section{Higgins 2008}

Higgins JPT, Green S. Cochrane Handbook for Systematic Reviews of Interventions Version 5.0.1 [updated February 2008]. The Cochrane Collaboration, 2008. www.cochranehandbook.org.

\section{Jaffe 1990}

Jaffe, J. Drug addiction and drug abuse. In: A Gilman, T Rall, A Nies, P Taylor editor(s). The pharmacological basis

\section{CHARACTERISTICS OF STUDIES}

Characteristics of included studies [ordered by study ID] of therapeutics. 8th Edition. New York: Pergamon Press, 1990:522-73.

\section{Lind 2005}

Lind B, Chen S, Weatherburn D, Mattick R. The effectiveness of methadone maintenance treatment in controlling crime. An Australian aggregate-level analysis. Journal of Criminology 2005;45:201-11.

\section{Mattick 1993}

Mattick R P, Hall W. A treatment outline for approaches to opioid dependence: Quality assurance project. Canberra: Australian Government Publishing Service, 1993.

\section{Mattick 1996 \\ Mattick RP, Hall W. Are detoxification programmes effective?. Lancet 1996;347:97-100.}

\section{Ward 1992}

Ward J, Mattick R P, Hall W. Key issues in methadone maintenance treatment. Sydney: New South Wales University Press, 1992.

\section{Ward 1998}

Ward J, Mattick R.P, Hall W. M. Methadone Maintenance Treatment and Other Opioid Replacement Therapies. Harwood Academic Publishers, 1998.

\section{Dolan 2003}

Methods Two group, open, randomised controlled trial. Randomisation: in blocks of ten by randomly drawing cards from an envelope. List of case numbers and group allocation not known to researcher or trial nurse. Follow up for four months.

Geographic region: Australia
Study setting: Prison. Participants were inmates on a waiting list for MMT.
$\mathrm{n}=382$ males
mean age $=27$ years
Eligibility criteria: heroin problem confirmed by medical interview, serving sentences of more than four
months, and able to provide informed consent.

Interventions Treatment: methadone maintenance treatment - flexible dose (mean 61mg, range 1-180mg). Control: wait-list.

\section{Risk of bias}

\begin{tabular}{lll}
\hline Bias & Authors' judgement & Support for judgement \\
\hline $\begin{array}{l}\text { Adequate sequence gener- } \\
\text { ation? }\end{array}$ & Low risk & Drawing lots. \\
\hline
\end{tabular}


Dolan 2003 (Continued)

\begin{tabular}{lll} 
Allocation concealment? & Low risk & A-Adequate. Central allocation. \\
\hline $\begin{array}{l}\text { Incomplete outcome data } \\
\begin{array}{l}\text { addressed? } \\
\text { All outcomes }\end{array}\end{array}$ & Low risk & $\begin{array}{l}\text { Missing outcome information balanced between groups. } 191 \text { randomised to } \\
\text { each group, } 124 \text { and } 129 \text { followed up in each group. }\end{array}$ \\
\hline Free of other bias? & Low risk & Baseline characteristics similar. \\
\hline
\end{tabular}

\section{Dole 1969}

Methods Two group, open, randomised controlled trial. Randomisation: release dates of treatment applicants were selected by lottery. Applicants who were not selected and demonstrated motivation for treatment became untreated controls. Follow-up for 50 weeks.

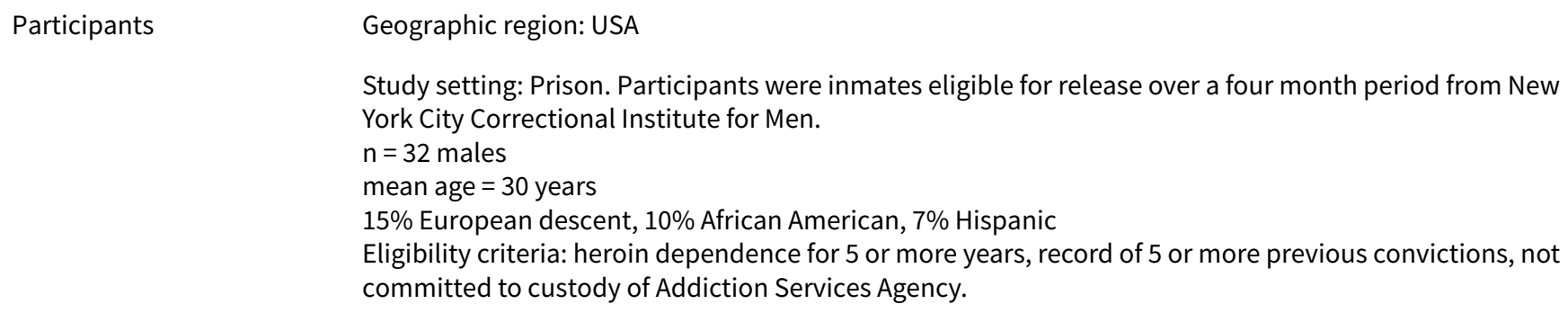

Study setting: Prison. Participants were inmates eligible for release over a four month period from New York City Correctional Institute for Men.

$\mathrm{n}=32$ males

mean age $=30$ years

15\% European descent, 10\% African American, 7\% Hispanic

Eligibility criteria: heroin dependence for 5 or more years, record of 5 or more previous convictions, not committed to custody of Addiction Services Agency.

\begin{tabular}{ll}
\hline Interventions & Control: wait-list \\
& Treatment: 10 day methadone maintenance pre-release. \\
Initial dose $10 \mathrm{mg}$, increasing to $35 \mathrm{mg}$ at release. \\
Continued methadone maintenance in outpatient clinic after release.
\end{tabular}

\section{Notes}

\section{Risk of bias}

\begin{tabular}{lll}
\hline Bias & Authors' judgement & Support for judgement \\
\hline $\begin{array}{l}\text { Adequate sequence gener- } \\
\text { ation? }\end{array}$ & High risk & Used release dates in a lottery. \\
\hline Allocation concealment? & Unclear risk & B- Unclear. Concealment of allocation not specified. \\
\hline $\begin{array}{l}\text { Incomplete outcome data } \\
\begin{array}{l}\text { addressed? } \\
\text { All outcomes }\end{array}\end{array}$ & Low risk & No missing data. \\
\hline \begin{tabular}{l} 
Free of other bias? \\
\hline
\end{tabular} & Low risk & \\
\hline
\end{tabular}

Gruber 2008

\begin{tabular}{ll}
\hline Methods & Three group randomised controlled trial. Randomisation: generated by statistician who placed as- \\
signments in sealed envelopes not revelaed to project staff. Allocation to group (21 day methadone
\end{tabular}


Gruber 2008 (Continued)

detoxification, 6 months methadone with minimal counselling or 6 months methadone with standard couselling) revealed at conclusion of baseline interview.

\begin{tabular}{|c|c|}
\hline \multirow[t]{7}{*}{ Participants } & Geographic region: USA \\
\hline & Study setting Outpatient hospital detoxification program. \\
\hline & $\mathrm{n}=111,68 \%$ male \\
\hline & mean age $=41.9$ years \\
\hline & 54\% White, 30\% African American, 20\% Hispanic, 4\% Native American, 5\% Asian/Pacific Islander \\
\hline & $85 \%$ unmarried \\
\hline & $\begin{array}{l}\text { Eligibility criteria; latent TB infection, DSM III R opioid dependence, aged 21-59, and willingness to re- } \\
\text { ceive isonaid preventive therapy and MMT. Excluded if pregnant or HIV positive or active liver disease. }\end{array}$ \\
\hline Interventions & $\begin{array}{l}\text { Treatment: } 6 \text { months methadone maintenance with minimal or standard counselling, followed by } 6 \\
\text { week taper. Control: } 21 \text { day methadone detoxification. }\end{array}$ \\
\hline Outcomes & $\begin{array}{l}\text { Retention } \\
\text { Illicit drug use - self report and urinalysis (monthly) }\end{array}$ \\
\hline \multirow[t]{3}{*}{ Notes } & $\begin{array}{l}\text { Results from the standard counseling and minimal counseling groups have been combined and com- } \\
\text { pared to the detoxification group. }\end{array}$ \\
\hline & $\begin{array}{l}\text { Unpublished data - the author provided additional data to enable the coding of retention and heroin } \\
\text { use. }\end{array}$ \\
\hline & All participants have active TB infection - study part of a larger study examining TB. \\
\hline
\end{tabular}

\section{Risk of bias}

\begin{tabular}{|c|c|c|}
\hline Bias & Authors' judgement & Support for judgement \\
\hline $\begin{array}{l}\text { Adequate sequence gener- } \\
\text { ation? }\end{array}$ & Low risk & "generated by a statistician". \\
\hline Allocation concealment? & Unclear risk & $\begin{array}{l}\text { B - Unclear. Individual sealed envelope not revealed to project staff. Does not } \\
\text { state opaque. }\end{array}$ \\
\hline $\begin{array}{l}\text { Incomplete outcome data } \\
\text { addressed? } \\
\text { All outcomes }\end{array}$ & Low risk & 4 in detox group in MMT elsewhere \\
\hline Free of other bias? & Low risk & $\begin{array}{l}\text { At baseline standard MMT group younger and detox group had more depres- } \\
\text { sive symptoms. }\end{array}$ \\
\hline
\end{tabular}

Gunne 1981

\begin{tabular}{ll}
\hline Methods & $\begin{array}{l}\text { Two group randomised clinical trial. Randomisation: after eligibility established subjects were random- } \\
\text { ly allocated to methadone maintenance or to drug-free treatment. Foow up for two years. }\end{array}$ \\
\hline Participants & Geographic region: Sweden \\
& Study setting: psychiatric research centre \\
$n=34,76 \%$ male
\end{tabular}


Gunne 1981 (Continued)

Eligibility criteria: $20-24$ years, history of at least 4 years IV heroin use, withdrawal signs and positive urine on admission, a minimum of three completed detoxifications, not arrested or serving a sentence and no dominate abuse of non-opiate drugs. Exclusion: active infectious disease.

\begin{tabular}{ll}
\hline Interventions & Control: no treatment, could not apply for the methadone program for two years. \\
& Treatment: methadone maintenance treatment, no dosage information reported. \\
\hline Outcomes & $\begin{array}{l}\text { Illicit drug use / Urinalysis (3 } \times \text { week) } \\
\text { Criminality } \\
\text { Vocational adjustment } \\
\text { Health } \\
\text { Mortality }\end{array}$ \\
\hline Notes & 2 controls obtained methadone from private practitioners and were excluded. \\
\hline
\end{tabular}

\section{Risk of bias}

\begin{tabular}{lll}
\hline Bias & Authors' judgement & Support for judgement \\
\hline $\begin{array}{l}\text { Adequate sequence gener- } \\
\text { ation? }\end{array}$ & Unclear risk & "Randomly allocated" \\
\hline Allocation concealment? & Unclear risk & B - Unclear \\
\hline $\begin{array}{l}\text { Incomplete outcome data } \\
\text { addressed? }\end{array}$ & Low risk & $\begin{array}{l}\text { No missing data. All controls refused drug free treatment and asked for dis- } \\
\text { charge. }\end{array}$ \\
\hline \begin{tabular}{l} 
Free of other bias? \\
\hline
\end{tabular} & Low risk & Only indiv 20-24. Baseline groups similar except gender - more women in MMT. \\
\hline
\end{tabular}

Kinlock 2007

$\begin{array}{ll}\text { Methods } & \text { Three group randomised controlled trial. Randomisation: after eligibility established subjects were } \\ & \text { randomly allocated to one of three groups. Randomisation process not described. Follow up for one } \\ \text { month. }\end{array}$
month.

Geographic region: USA
Study setting: Prison. Participants were inmates due for release in 3-6 months.
$\mathrm{n}=211$ males
mean age $=40.3$ years
$70 \%$ African American, $24 \%$ Caucasian
Eligibility criteria: DSM IV heroin dependence at time of incarceration, suitability for MMT as deter-
mined by medical assessment, willingness to enrol in prison MMT and residing in Baltimore on release.
Individuals that did not meet dependence criteria were eligible if they had been enrolled in an opiate
treatment program the year prior to incarceration.

Interventions Treatment: Counseling and methadone maintenance in prison with transfer into treatment on release. Target methadone dose $60 \mathrm{mg}$.

Control: Counseling in prison with passive referal to treatment upon release

\begin{tabular}{ll}
\hline Outcomes & Entry into community MMT \\
Illicit drug use - self report and urinalysis
\end{tabular}


Kinlock 2007 (Continued)

Notes

A third group received counseling in prison and active referal to MMT on release group. These results have not been included in the analysis.

\section{Risk of bias}

\begin{tabular}{lll}
\hline Bias & Authors' judgement & Support for judgement \\
\hline $\begin{array}{l}\text { Adequate sequence gener- } \\
\text { ation? }\end{array}$ & Low risk & Block randomisation procedure. \\
\hline Allocation concealment? & Unclear risk & B- Unclear. Not specified. \\
\hline $\begin{array}{l}\text { Incomplete outcome data } \\
\begin{array}{l}\text { addressed? } \\
\text { All outcomes }\end{array}\end{array}$ & Low risk & No missing data. Report ITT \\
\hline \begin{tabular}{l} 
Free of other bias? \\
\hline
\end{tabular} & Low risk & No differences between group at baseline. \\
\hline
\end{tabular}

Newman 1979

\begin{tabular}{ll}
\hline Methods & Double blind randomised clinical trial \\
Randomisation: subjects randomly allocated on discharge from hospital after 2 week stabilisation on \\
$60 \mathrm{mg}$ methadone to detoxification or continued maintenance.
\end{tabular}

Geographic region: Hong Kong
Study setting: Hospital and outpatient clinic
$\mathrm{n}=100$ males
mean age $=38$ years
Eligibility criteria: male, 22-58 years, history of heroin dependence for at least 4 years and at least one
previous treatment, current heroin dependence by three consecutive positive urine samples, voluntary
application for admission (criminal justice referrals excluded), resident with fixed address, absence of
past or present major psychiatric or medical illness.

\begin{tabular}{ll}
\hline Interventions & Treatment: methadone maintenance - flexible dose (average $97 \mathrm{mg} /$ day). \\
& Control: detoxification from $60 \mathrm{mg}$ methadone at $1 \mathrm{mg} /$ day for 60 days, placebo the \\
\hline Outcomes & Illicit drug use / Urinalysis (daily collection, analysed $2 \mathrm{x}$ week for morphine only) \\
& Retention \\
& Criminal activity \\
& Mortality
\end{tabular}

\section{Notes}

\section{Risk of bias}

\begin{tabular}{lll}
\hline Bias & Authors' judgement & Support for judgement \\
\hline $\begin{array}{l}\text { Adequate sequence gener- } \\
\text { ation? }\end{array}$ & Unclear risk & 'Randomly assigned' \\
\hline Allocation concealment? & Low risk & $\begin{array}{l}\text { A - Adequate 'neither patients nor clinic staff knew which group' 'pharmacist } \\
\text { only staff aware'. }\end{array}$ \\
\hline $\begin{array}{l}\text { Incomplete outcome data } \\
\text { addressed? }\end{array}$ & Low risk & No missing data. Report ITT. \\
\hline
\end{tabular}


Newman 1979 (Continued)

All outcomes

Free of other bias? Low risk No difference between group at baseline

Schwartz 2006

Methods Two group randomised controlled trial with participants randomised to interim methadone mainte-
nance treatment or a wait list control. Random assignment generated by random number table and sealed in an envelope.

Geographic region: USA
Study setting: community methadone treatment facility.
$\mathrm{n}=319,59 \%$ male
mean age $=41.4$ years
$93 \%$ African American
$62 \%$ unemployed
Eligibility criteria; DSM IV heroin dependence and informed consent. Exclusions; pregnant or acute
medical or psychiatric illness.

Interventions Treatment: interim methadone maintenance treatment for 120 days after which entry into a comprehensive methadone treatment program if unable to gain entry before 120 days.

Control: wait-list

Outcomes Entry into comprehensive methadone maintenance treatment at 4 months.
Illicit drug use /self report and urinalysis. Criminal activity.

Mobile program that at time of study administered methadone from specially equipped recreational
vehicle

\section{Risk of bias}

\begin{tabular}{|c|c|c|}
\hline Bias & Authors' judgement & Support for judgement \\
\hline $\begin{array}{l}\text { Adequate sequence gener- } \\
\text { ation? }\end{array}$ & Low risk & 'table of random numbers' \\
\hline Allocation concealment? & Unclear risk & $\begin{array}{l}\text { B - Unclear. Sealed envelope but unclear if opaque and sequentially num- } \\
\text { bered. }\end{array}$ \\
\hline $\begin{array}{l}\text { Incomplete outcome data } \\
\text { addressed? } \\
\text { All outcomes }\end{array}$ & Low risk & $\begin{array}{l}\text { Missing outcome information balanced between groups. 95\% MMT and 89\% } \\
\text { wait list located for follow up. }\end{array}$ \\
\hline Free of other bias? & Low risk & No difference between group at baseline \\
\hline
\end{tabular}

Sees 2000

$\begin{array}{ll}\text { Methods } & \text { Two group randomised controlled trial. Randomisation: participants randomly allocated from strati- } \\ \text { fied blocks to methadone maintenance treatment or 180-day methadone assisted detoxification. }\end{array}$


Sees 2000 (Continued)
Participants
Geographic region: USA
Study setting: Medical Center
$\mathrm{n}=179,59 \%$ male
mean age $=39.4$ years
52\% Caucasian, 30\% African American, 13\% Hispanic
$53 \%$ unemployed, $79 \%$ unmarried
Eligibility criteria: opioid depeendent and urine screen positive for opioid and negative for methadone.

Treatment: methadone maintenance for 14 months followed by a 2 month detoxification. Participants
required to attend $1 \mathrm{hr} /$ wk group therapy and $1 \mathrm{hr} /$ wh individual theray for first 6 months.
Flexible dose (max dose of $100 \mathrm{mg} / \mathrm{d})$
Control: 14 months of substance abuse treatment. 120 days induction and methadone maintenance
followed by 60 days of dose reductions. Participants were required to attend $2 \mathrm{hr} /$ wk group therapy,
$1 \mathrm{hr} /$ week education classes and weekly individal therapy sessions. During month $7-14$ participants of-
fered nonmethadone aftercare treatment - group and individual therapy and liaison services with crim-
inal justice, medical clinics and social services.

\begin{tabular}{ll}
\hline Outcomes & Retention \\
& Illicit drug use - self report and monthly urinalysis. \\
& HIV risk behaviours
\end{tabular}

Notes Retention data was taken at 180 days from Fig 3 in the published paper.

\section{Risk of bias}

\begin{tabular}{|c|c|c|}
\hline Bias & Authors' judgement & Support for judgement \\
\hline $\begin{array}{l}\text { Adequate sequence gener- } \\
\text { ation? }\end{array}$ & Low risk & 'generated via computer software by statistician using various block sizes' \\
\hline Allocation concealment? & Unclear risk & $\begin{array}{l}\text { B - Unclear 'kept in sealed envelope'. Unclear if opaque and sequentially num- } \\
\text { bered. }\end{array}$ \\
\hline $\begin{array}{l}\text { Incomplete outcome data } \\
\text { addressed? } \\
\text { All outcomes }\end{array}$ & Low risk & Missing outcome information balanced between group. \\
\hline Free of other bias? & Low risk & No differences between group at baseline. \\
\hline
\end{tabular}

Strain 1993a

Methods Three group, double-blind, placebo controlled randomised controlled trial. Patients were stratified by race and sex and randomly assigned to a fixed dose schedule at admission.

Treatment group assignment, stabilisation dose and dosing schedules were blind to patient and clinic staff with patient contact.

\begin{tabular}{ll}
\hline Participants & Geographic region: USA \\
Study setting: methadone treatment research clinic \\
$\mathrm{n}=247,70 \%$ male \\
mean age $=34$ years \\
$50 \%$ African American \\
$62 \%$ unemployed, $84 \%$ unmarried
\end{tabular}


Strain 1993a (Continued)

Eligibility criteria: $18-50$ years, history of IV opioid dependence, no chronic medical illness, absence of major mental illness, negative pregnancy test and at least three months since last treatment at the clin-

ic.

$\begin{array}{ll}\text { Interventions } & \text { Initial treatment of active methadone for at least } 5 \text { weeks. } \\ & 15 \text { weeks of stable dosing at 50, } 20 \text { or } 0 \mathrm{mg} \text { per day } \\ \text { Gradual tapering for those receiveing active methadone from weeks 21-26 } \\ \text { Individual counselling and group therapy (weekly). }\end{array}$

\begin{tabular}{ll}
\hline Outcomes & Retention \\
& $\begin{array}{l}\text { Treatment compliance } \\
\text { Illicit drug use / Urinalysis (collected } 3 \times \text { weekly, one sample selected at random for analysis for opi- } \\
\text { oids, cocaine and benzodiazepines) }\end{array}$ \\
\hline Notes & $\begin{array}{l}\text { A subsample of } 0 \mathrm{mg} \text { patients }(\mathrm{n}=44) \text { received an } 8 \text { week induction, reaching 0mg at } 9 \text { weeks. Data for } \\
\text { patients in alternate } 0 \mathrm{mg} \text { treatment groups are collapsed }\end{array}$
\end{tabular}

\section{Risk of bias}

\begin{tabular}{lll}
\hline Bias & Authors' judgement & Support for judgement \\
\hline $\begin{array}{l}\text { Adequate sequence gener- } \\
\text { ation? }\end{array}$ & Unclear risk & $\begin{array}{l}\text { 'randomly assigned' stratified by race and sex. Unclear not enough informa- } \\
\text { tion. }\end{array}$ \\
\hline Allocation concealment? & Unclear risk & B - Unclear \\
\hline $\begin{array}{l}\text { Incomplete outcome data } \\
\begin{array}{l}\text { addressed? } \\
\text { All outcomes }\end{array}\end{array}$ & Low risk & \\
\hline \begin{tabular}{l} 
Free of other bias? \\
\hline
\end{tabular} & Low risk & Baseline groups similar. \\
\hline
\end{tabular}

\section{Vanichseni 1991}

\begin{tabular}{ll}
\hline Methods & $\begin{array}{l}\text { Two group, open label, randomised clinical trial, with participants who applied for } 45 \text { day methadone } \\
\text { detoxification and had at least six prior treatment episodes were randomly assigned to methadone } \\
\text { maintenance or detoxification }\end{array}$ \\
\hline Participants & $\begin{array}{l}\text { Geographic region: Thailand } \\
\text { Study setting: narcotics clinic } \\
\mathrm{n}=240 \text { males }\end{array}$ \\
$30 \%$ unemployed, $52 \%$ unmarried \\
Eligibility criteria: heroin injectors applying for 45-day detoxification, at least 6 prior treatment \\
episodes at the clinic.
\end{tabular}

\section{Notes}


Vanichseni 1991 (Continued)

\section{Risk of bias}

\begin{tabular}{lll}
\hline Bias & Authors' judgement & Support for judgement \\
\hline $\begin{array}{l}\text { Adequate sequence gener- } \\
\text { ation? }\end{array}$ & Unclear risk & Unclear. Not enough information provided. \\
\hline Allocation concealment? & Unclear risk & B - Unclear \\
\hline $\begin{array}{ll}\text { Incomplete outcome data } \\
\text { addressed? }\end{array}$ & Low risk & Urine provided for drop outs. \\
All outcomes & \\
\hline Free of other bias? & Low risk & \\
\hline
\end{tabular}

\section{Yancovitz 1991}

$\begin{array}{ll}\text { Methods } & \begin{array}{l}\text { Two group randomised clinical trial, with opioid dependent participants on waiting-lists for compre- } \\ \text { hensive methadone maintenance programs who were randomised to either the interim methadone } \\ \text { program or wait list with frequent contact. }\end{array}\end{array}$

\begin{tabular}{ll}
\hline Participants & Geographic region: USA \\
Study setting: interim methadone clinic \\
$\mathrm{n}=301,79.4 \%$ male \\
$55 \%$ Hispanic, $35 \%$ African American, $10 \%$ White \\
$86 \%$ unemployed \\
Eligibilty criteria: wait list for comprehensive methadone maintenance program.
\end{tabular}

\begin{tabular}{ll}
\hline Interventions & $\begin{array}{l}\text { Control: wait-list with frequent contact } \\
\text { Treatment: "interim" methadone maintenance; standard physical exam on admission, flexible dos- } \\
\text { ing } 5 \text { days a week, pick up on weekends from another site, minimal counselling, referral to community } \\
\text { agencies }\end{array}$ \\
\hline Outcomes & $\begin{array}{l}\text { Urinalysis ( } 2 \times \text { weekly for heroin and cocaine) } \\
\text { Entry into conventional treatment }\end{array}$ \\
\hline Notes & $\begin{array}{l}\text { For the first } 3 \text { months of the study there were three experimental groups; interim methadone, wait-list } \\
\text { with frequent contact and bi-weekly urinalysis, and the wait-list with no contact. Recruitment slowed } \\
\text { which resulted in the protocol being changed two experimental groups; interim methadone and wait- } \\
\text { list with frequent contact. The wait-list then only lasted one month at which time the participants were } \\
\text { switched to a methadone program. } \\
\text { Data from the initial discontinued minimal contact group is not include in the analysis. }\end{array}$
\end{tabular}

\section{Risk of bias}

\begin{tabular}{lll}
\hline Bias & Authors' judgement & Support for judgement \\
\hline $\begin{array}{l}\text { Adequate sequence gener- } \\
\text { ation? }\end{array}$ & Unclear risk & 'randomly assigned'. Not enough information \\
\hline Allocation concealment? & Low risk & A - Adequate. 'assigned by administrative staff at another location' \\
\hline $\begin{array}{l}\text { Incomplete outcome data } \\
\begin{array}{l}\text { addressed? } \\
\text { All outcomes }\end{array}\end{array}$ & Low risk & $\begin{array}{l}\text { Missing outcome information balanced between group. Follow up 50\% in MMT } \\
\text { and 36\% for control. }\end{array}$ \\
\hline
\end{tabular}


Yancovitz 1991 (Continued)

Free of other bias? Low risk No baseline differences.

Characteristics of excluded studies [ordered by study ID]

\begin{tabular}{ll}
\hline Study & Reason for exclusion \\
\hline Bale 1980 & $\begin{array}{l}\text { The authors planned to conduct a randomised controlled trial comparing methadone mainte- } \\
\text { nance, therapeutic communities and detoxification programs. Ethical and practical problems pre- } \\
\text { vented random assignment and the study therefore does not meet inclusion criteria for this review. }\end{array}$ \\
\hline Dolan 2005 & This paper presents follow up results from the study reported in Dolan 2003. \\
\hline Schwartz 2007 & This paper presents follow up results from the study reported in Schwartz 2006.
\end{tabular}

\section{DATA AND ANALYSES}

\section{Comparison 1. Methadone maintenance treatment vs No methadone maintenance treatment}

\begin{tabular}{|c|c|c|c|c|}
\hline Outcome or subgroup title & $\begin{array}{l}\text { No. of } \\
\text { studies }\end{array}$ & $\begin{array}{l}\text { No. of } \\
\text { partici- } \\
\text { pants }\end{array}$ & Statistical method & Effect size \\
\hline 1 Retention in treatment & 7 & & Risk Ratio (M-H, Random, 95\% Cl) & Subtotals only \\
\hline 1.1 Old studies (pre 2000) & 3 & 505 & Risk Ratio (M-H, Random, 95\% Cl) & $3.05[1.75,5.35]$ \\
\hline 1.2 New studies & 4 & 750 & Risk Ratio (M-H, Random, 95\% Cl) & $4.44[3.26,6.04]$ \\
\hline $\begin{array}{l}2 \text { Morphine positive urine or hair analy- } \\
\text { sis }\end{array}$ & 6 & 1129 & Risk Ratio (M-H, Random, 95\% Cl) & $0.66[0.56,0.78]$ \\
\hline 3 Self reported heroin use & 6 & & Risk Ratio (M-H, Random, 95\% Cl) & Subtotals only \\
\hline 4 Criminal activity & 3 & 363 & Risk Ratio (M-H, Random, 95\% Cl) & $0.39[0.12,1.25]$ \\
\hline 5 Mortality & 4 & 576 & Risk Ratio (M-H, Random, 95\% Cl) & $0.48[0.10,2.39]$ \\
\hline
\end{tabular}

Analysis 1.1. Comparison 1 Methadone maintenance treatment vs No methadone maintenance treatment, Outcome 1 Retention in treatment.

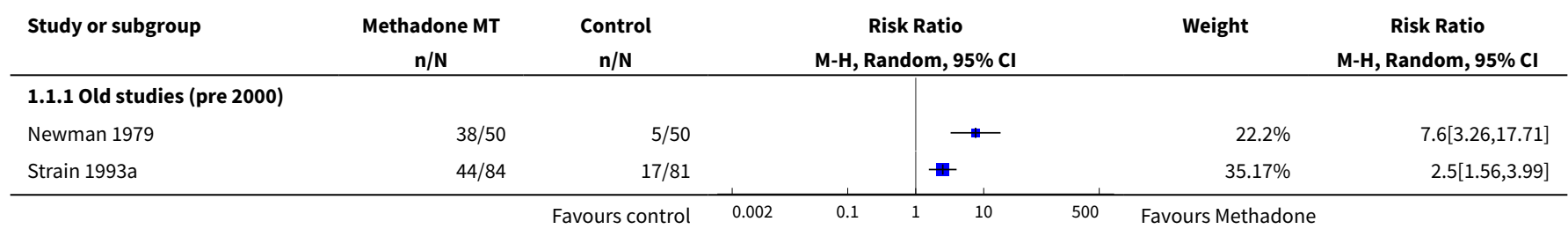




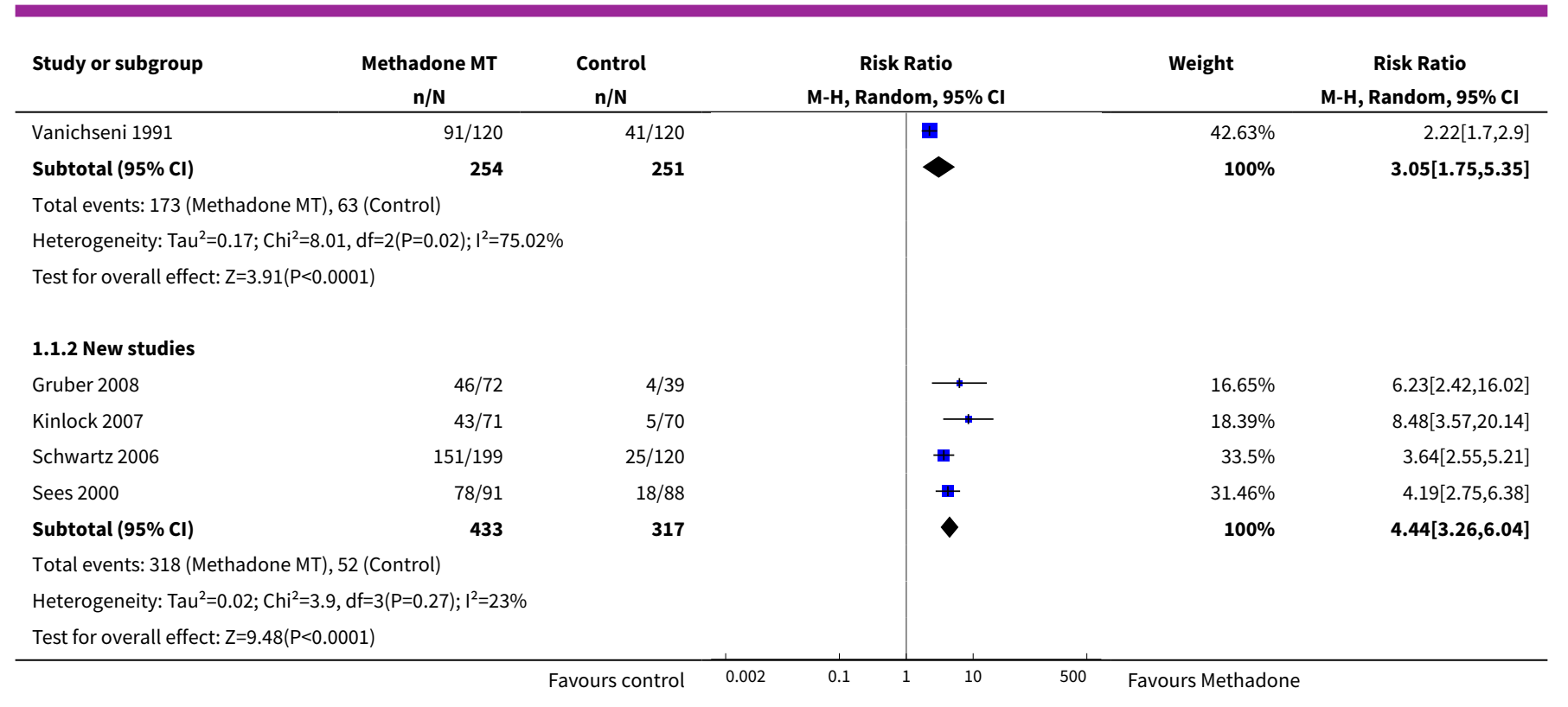

Analysis 1.2. Comparison 1 Methadone maintenance treatment vs No methadone maintenance treatment, Outcome 2 Morphine positive urine or hair analysis.

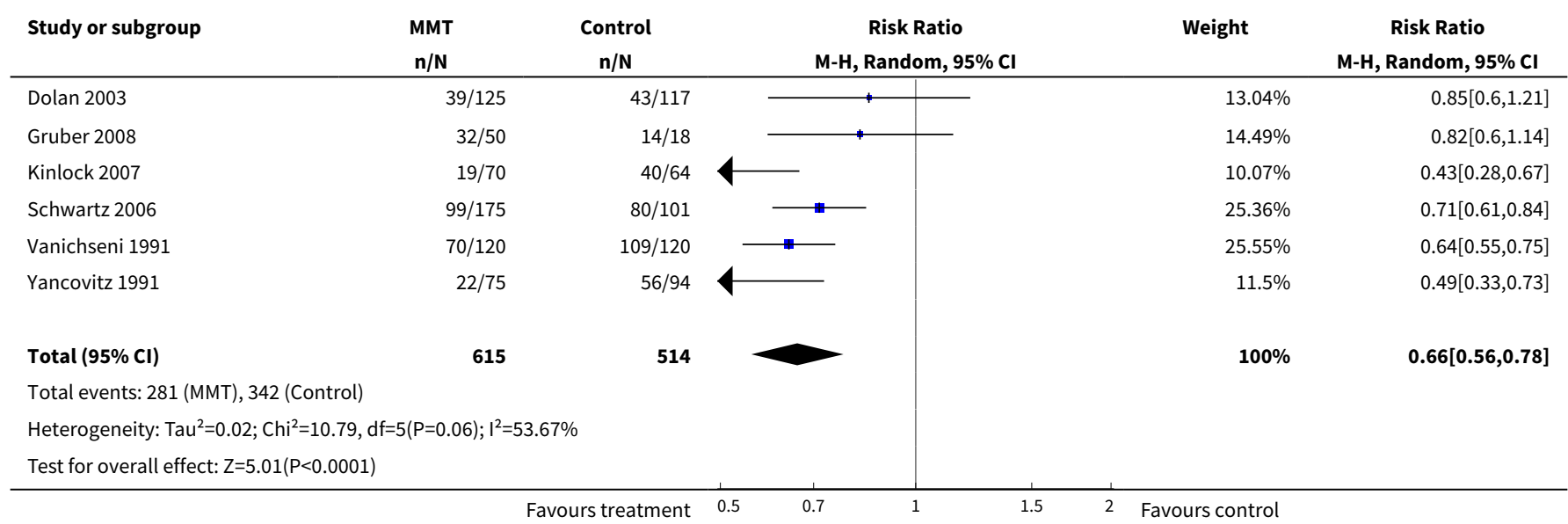

Analysis 1.3. Comparison 1 Methadone maintenance treatment vs No methadone maintenance treatment, Outcome 3 Self reported heroin use.

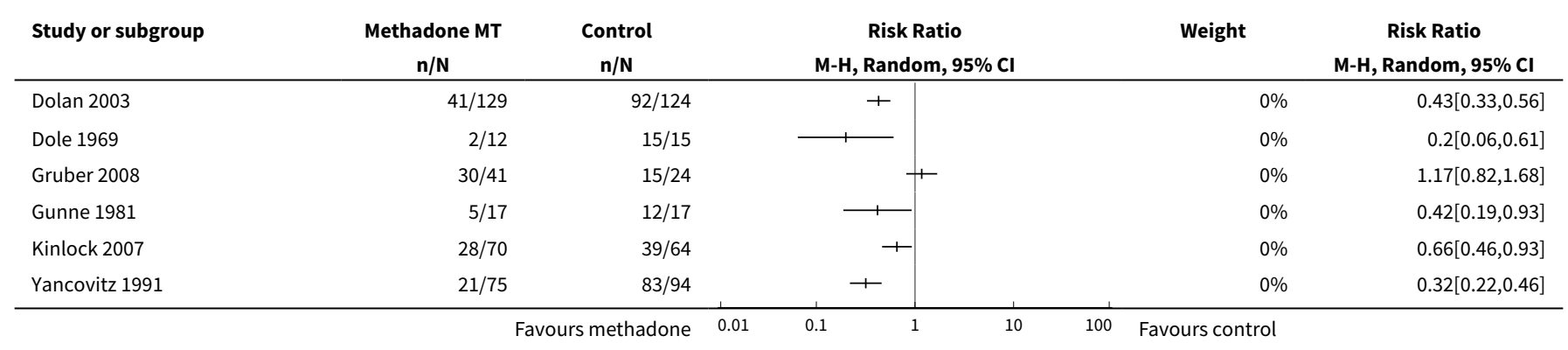


Analysis 1.4. Comparison 1 Methadone maintenance treatment vs No methadone maintenance treatment, Outcome 4 Criminal activity.

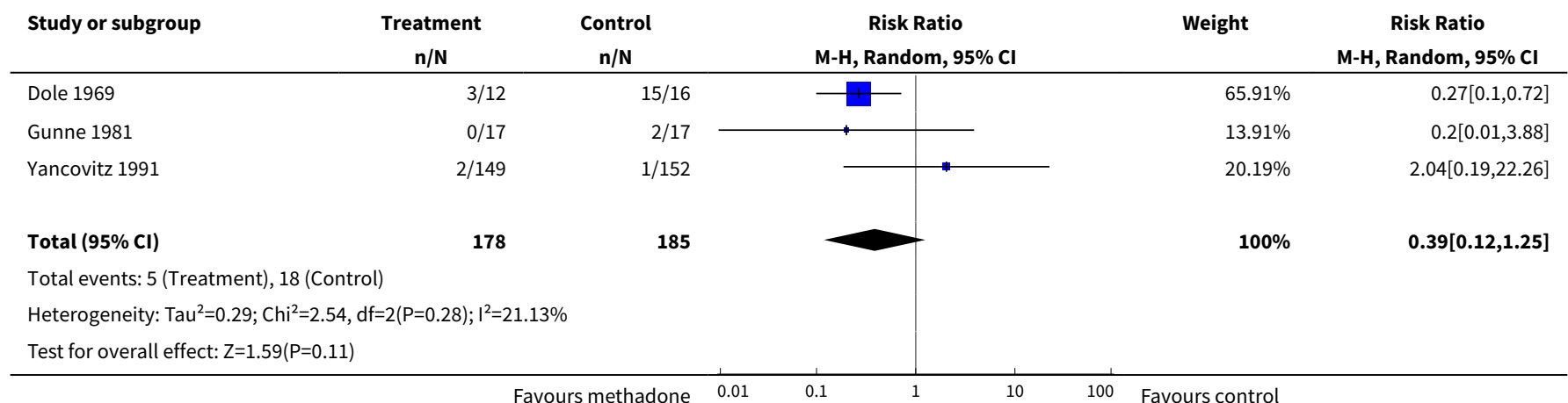

Analysis 1.5. Comparison 1 Methadone maintenance treatment vs No methadone maintenance treatment, Outcome 5 Mortality.

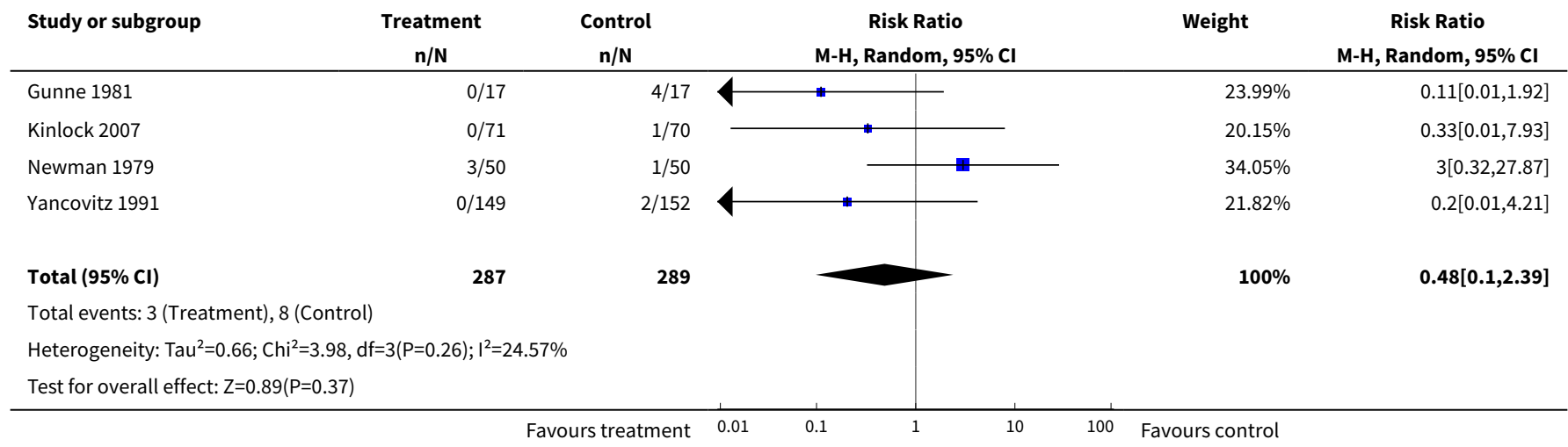

\section{APPENDICES}

\section{Appendix 1. Cochrane Central Register of Controlled Trials search strategy}

1. OPIOID-RELATED DISORDERS*:ME

2. (( ${ }^{\star}$ opioid or opiate) and ( ${ }^{*}$ abuse or dependen ${ }^{\star}$ or disorder ${ }^{\star}$ or addict $\left.\left.{ }^{\star}\right)\right)$

3.1 or 2

4. Heroin

5. Opioid ${ }^{\star}$ or Opiate*

6. \#3 or \#4 or \#5

7. METHADONE:ME or methadone

8. (placebo or withdraw* or detox* or untreated or "no treatment" or "drug free" or "wait list" or waiting)

9. \#6 and \#7

10. \#9 and \#8

\section{Appendix 2. PubMed search strategy}

1. "substance-related disorders" [MH]

2. "opioid related disorders" [MH]

3. (( ${ }^{\star}$ opioid OR opiate) AND ( ${ }^{\star}$ abuse OR dependen* OR disorder ${ }^{\star}$ OR addict $\left.{ }^{\star}\right)$ ) 
4. 1 OR 2

5. Heroin $[\mathrm{MH}] \mathrm{OR}$ heroin

6. Narcotics [MH]

7. opioid* OR opiate*

8. 5 OR 6 OR 7

9. 4 OR 8

10. methadone $[\mathrm{MH}]$ OR methadone

11. 9 AND 10

12. (placebo OR withdraw* OR detox* OR untreated OR "no treatment" OR "drug free" OR "wait list" OR waiting)

13. 11 AND 12

combined with the phases $1 \& 2$ of the Cochrane Sensitive Search Strategy for the identification of RCTs as published in Appendix 5b2, Cochrane Handbook for Systematic Reviews of Interventions (Higgins 2006)

14. randomized controlled trial $[\mathrm{PT}]$

15. randomized controlled trials $[\mathrm{MH}]$

16. controlled clinical trial [PT]

17. random allocation $[\mathrm{MH}]$

18. double blind method $[\mathrm{MH}]$

19. single blind method [MH]

20. 14 OR 15 OR 16 OR 17 OR 18 OR 19

21. clinical trial $[\mathrm{PT}]$

22. clinical trials $[\mathrm{MH}]$

23. ((singl ${ }^{\star}$ OR doubl ${ }^{\star}$ OR trebl ${ }^{\star}$ OR tripl $\left.{ }^{\star}\right)$ AND (blind ${ }^{\star}$ OR mask $\left.\left.{ }^{\star}\right)\right)$

24. PLACEBOS $[\mathrm{MH}]$ OR placebo*

25. random*

26. Research Design:ME

27. $14 / 26$ OR

28. 13 AND 27

29. limit 28 to human

\section{Appendix 3. EMBASE search strategy}

1. drug abuse.me

2. Substance abuse.me

3. ((opioid or opiate) and (abuse\$ or dependen\$ or disorder $\$$ or addict\$))

4. 1 or 2 or 3

5. heroin.mp

6. Opiate.me or opiate\$

7. opioid\$

8.5 or 6 or 7

9.4 and 8

10. methadone.me or methadone

11. methadone treatment.me

12. 10 or 11

13. 9 and 12

14. (placebo or withdraw\$ or untreated or "drug free" or detox\$ or "wait list" or waiting)

15. 13 and 14

16. random\$

17. placebo\$

18. (singl\$ or doubl\$ or trebl\$ or tripl\$) and (blind\$ or mask\$))

19. crossover\$

20. randomized controlled trial.me

21. phase-2-clinical-trial.me

22. phase-3-clinical-trial.me

23. double blind procedure.me

24. single blind procedure.me

25. crossover procedure.me

26. Latin square design.me

27. PLACEBOS.me

28. multicenter study.me

29.15 or 16 or 17 or 18 or 19 or 20 or 21 or 22 or 23 or 24 or 25 or 26 or 27 or 28

30. 15 and 29 
31. limit 30 to human

\section{Appendix 4. CINAHL search strategy}

1. exp "Substance Use Disorders"/

2. ((drug or substance) and (addict ${ }^{\star}$ or dependen ${ }^{\star}$ or abuse* or disorder $\left.{ }^{\star}\right)$ )

3. 1 or 2

4. exp heroin/ or heroin

5. (opioid ${ }^{\star}$ or opiate ${ }^{\star}$ )

6. exp methadone/ or methadone

7.3 or 4 or 5 or 6

8. (placebo or withdraw* or untreated or "drug free" or detox* or "wait list" or waiting)

9. 7 and 8

10. random*

11. (singl ${ }^{\star}$ or doubl ${ }^{\star}$ or tripl ${ }^{\star}$ or trebl $\left.{ }^{\star}\right)$ and $\left(\right.$ mask $^{\star}$ or blind $\left.^{\star}\right)$

12. crossover ${ }^{\star}$

13. allocate ${ }^{\star}$

14. assign $^{*}$

15. $\left(\left(\right.\right.$ (andom $\left.^{\star}\right)$ and (allocate* or assign $\left.\left.{ }^{\star}\right)\right)$

16. exp Random Assignment/

17. exp Clinical Trials/

18. 10 or 11 or 12 or 13 or 14 or 15 or 16 or 17

19. 9 and 18

\section{WHAT'S NEW}

\begin{tabular}{lll}
\hline Date & Event & Description \\
\hline 5 March 2009 & $\begin{array}{l}\text { New citation required but conclusions } \\
\text { have not changed }\end{array}$ & $\begin{array}{l}\text { new trials included, analysis changed in respect to the previous } \\
\text { version, quality assessment changed following the new rules of } \\
\text { the Collaboration }\end{array}$ \\
\hline 19 February 2009 & New search has been performed & new search, new studies found \\
\hline
\end{tabular}

\section{H I S T O R Y}

Protocol first published: Issue 3, 2000

Review first published: Issue 4, 2002

\begin{tabular}{lll}
\hline Date & Event & Description \\
\hline 23 February 2003 & $\begin{array}{l}\text { New citation required and conclusions } \\
\text { have changed }\end{array}$ & Substantive amendment \\
\hline
\end{tabular}

\section{CONTRIBUTIONS OF AUTHORS}

Contributions: Richard P Mattick, Jo Klimber and Courtney Breen reviewed the papers, with Courtney Breen and Richard P. Mattick coding data from the papers for meta-analysis.

Richard P. Mattick conceptualised the review and Courtney Breen conducted the initial literature searches.

Richard P. Mattick wrote the analysis sections and discussion. Marina Davoli was the contact editor of the review and contributed to the writing of the final version of the review.

The review was updated by Richard P. Mattick and Courtney Breen. 


\section{DECLARATIONS OF INTEREST}

The first reviewer, Richard P. Mattick, is the fourth author on the Australian trial of methadone maintenance versus wait-list control in a prison setting (Dolan 2003).

\section{SOURCES OF SUPPORT}

\section{Internal sources}

- National Drug and Alcohol Research Centre, University of New South Wales, Sydney, Australia.

\section{External sources}

- Commonwealth Department of Health and Aged Care, Canberra, Australia.

\section{INDEX TERMS}

\section{Medical Subject Headings (MeSH)}

Inactivation, Metabolic; Methadone [ ${ }^{\star}$ therapeutic use]; Narcotics [ ${ }^{\star}$ therapeutic use]; Opioid-Related Disorders [ ${ }^{\star}$ rehabilitation]; Randomized Controlled Trials as Topic

\section{MeSH check words}

Humans 